\title{
KETERAMPILAN MENULIS CERPEN BERDASARKAN KOMIK WEBTOON SISWA KELAS IX-D MTSN 2 KOTA BANJARMASIN
}

\section{SKILLS WRITE SHORT STORIES BASED ON WEBTOON COMICS STUDENTS CLASS IX-D MTSN 2 KOTA BANJARMASIN}

\author{
Ainun Purnama Laili; Sabhan; Sainul Hermawan \\ Program Studi Pendidikan Bahasa dan Sastra Indonesia \\ FKIP Universitas Lambung Mangkurat \\ aynunpurnama@gmail.com
}

\begin{abstract}
Abstrak
Penelitian ini bertujuan untuk mendeskripsikan keterampilan menulis cerpen berdasarkan Komik Webtoon siswa kelas IX-D MTsN 2 Kota Banjarmasin berdasarkan aspek kebahasaan dan aspek kesastraan. Metode deskriptif dengan pendekatan kualitatif dan kuantitatif dipakai dalam penelitian ini. Berdasarkan analisis data, diketahui bahwa siswa baik dalam membuat cerpen berdasarkan tema dan amanat yang terdapat dalam Komik Webtoon yang dibaca. Penelitian yang dilakukan dapat disimpulkan dari aspek kebahasaan berupa penggunaan ejaan dan aspek kesastraan berupa tokoh dan penokohan, latar, alur, dan sudut pandang. Dari 32 siswa, 21 siswa (65,63\%) dikategorikan baik, 10 siswa (31,25\%) dikategorikan cukup baik, dan 1 siswa $(3,12 \%)$ dikategorikan kurang baik. Berdasarkan data tersebut, keterampilan menulis cerpen siswa kelas IX-D MTsN 2 Kota Banjarmasin dikategorikan baik (terampil), dengan persentase $65,63 \%$.

Kata kunci: menulis, keterampilan menulis, cerpen.

Abstract

This study aims to describe the short story writing skills based on the Webtoon Comics grade IX-D students of MTsN 2 Banjarmasin City based on linguistic and literary aspects. Descriptive methods with qualitative and quantitative approaches are used in this study. Based on data analysis, it is known that students are good at making short stories based on the themes and mandates contained in the Webtoon Comics that are read. The research conducted can be concluded from the linguistic aspects in the form of the use of spelling and literary aspects in the form of characters and characterizations, settings, plot, and point of view. Of the 32 students, 21 students (65.63\%) were categorized as good, 10 students (31.25\%) were categorized quite well, and 1 student (3.12\%) was classified as unfavorable. Based on these data, short story writing skills of class IX-D students of MTsN 2 Banjarmasin City are categorized as good (skilled), with a percentage of $65.63 \%$.

Keywords: writing, writing skills, short stories.
\end{abstract}




\section{Pendahuluan}

Berdasarkan riset pendahuluan tentang menulis, diketahui bahwa siswa banyak yang menganggap sulit keterampilan menulis. Sukino (2010: 13) menyatakan bahwa berdasarkan pengalaman seseorang dalam membuat tulisan rata-rata memiliki kesamaan, yaitu kesulitan mengungkapkan atau menuliskan ide. Hal tersebut merupakan penyebab banyak siswa kurang tertarik untuk membuat sebuah karangan, contohnya cerpen. Akan tetapi, diketahui bahwa membaca karangan orang lain dapat memotivasi dan memberikan ide untuk menulis. Hal ini dapat diterapkan pada pembelajaran menulis cerpen.

Perkembangan zaman membuat penggunaan media sosial banyak diminati oleh masyarakat. Hal ini karena pada media sosial tidak hanya dimuat berbagai informasi dalam bentuk teks, namun juga dalam berbagai bentuk lain seperti audio, gambar, dan video. Contoh layanan menarik yang ditawarkan oleh media sosial ialah komik. Komik Webtoon merupakan komik daring yang mudah diakses dan dapat dibaca oleh penggunanya secara gratis. Oleh karena itu, sekarang banyak orang yang menyukainya.

Berdasarkan hasil observasi terhadap siswa MTsN 2 Kota Banjarmasin, dapat diketahui bahwa sejumlah siswa suka membaca Komik Webtoon. Contohnya siswa di kelas IX-D. Dari 32 siswa, 19 siswa menyatakan suka membaca Komik Webtoon dengan berbagai alasan. Alasan-alasan tersebut yaitu karena tertarik dengan jalan ceritanya, mudah diakses dengan ponsel, terdapat pesan yang dapat diambil pelajaran, dan dapat memberikan inspirasi.

Penelitian tentang keterampilan menulis menggunakan media Komik Webtoon sudah pernah dilakukan pada materi drama, yaitu tesis yang ditulis oleh Atika pada 2018 dengan judul "Pengembangan Media Pembelajaran Menulis Drama dengan Webtoon di Kelas VIII SMP". Hasil penelitian tersebut menunjukkan bahwa Webtoon baik digunakan sebagai media dalam menulis drama. Pada penelitan ini, media tersebut digunakan untuk memudahkan siswa menulis cerpen.

Berdasarkan penjelasan yang telah diuraikan, penelitian ini berjudul "Keterampilan Menulis Cerpen Berdasarkan Komik Webtoon Siswa Kelas IX-D MTsN 2 Kota Banjarmasin". Masalah yang diteliti tentang bagaimana keterampilan menulis cerpen berdasarkan Komik Webtoon siswa di kelas IX-D MTsN 2 Kota Banjarmasin. Penelitian ini memiliki tujuan untuk 
mendeskripsikan keterampilan menulis cerpen berdasarkan Komik Webtoon.

\section{Metode Penelitian}

Jenis Penelitian

Metode deskriptif dipakai dengan melalui pendekatan kualitatif dan kuantitatif. Selain mendeskripsikan data menggunakan deskriptif kualitatif, dilakukan juga perhitungan menggunakan skor dengan kuantitatif untuk memudahkan peneliti menganalisis datanya.

\section{Waktu dan Tempat Penelitian}

Pengumpulan dan analisis data pada penelitian ini dilakukan selama dua bulan. Tempat penelitian ini dilakukan di MTsN 2 Kota Banjarmasin.

\section{Subjek Penelitian}

Subjek yang diteliti ialah 32 orang siswa kelas IX-D MTsN 2 Kota Banjarmasin. Kelas IX-D dipilih karena merupakan kelas dengan jumlah siswa penyuka Komik Webtoon terbanyak dibandingkan dengan kelas IX yang lain.

\section{Prosedur}

Peneliti melakukan observasi dan wawancara guru Bahasa Indonesia dan siswa MTsN 2 Kota Banjarmasin. Setelah itu, peneliti melakukan pengumpulan data berupa teks cerpen yang ditulis oleh siswa berdasarkan Komik Webtoon.

\section{Data, Instrumen, dan Teknik Pengumpulan Data}

Data yang diteliti berupa deskripsi pembelajaran dan dokumen teks cerpen yang dibuat oleh masing-masing siswa. Instrumen penelitian dibuat berdasarkan kriteria terampil menulis cerpen dari aspek kebahasaan dan kesastraan untuk memudahkan peneliti melakukan analisis data. Data dikumpulkan melalui uji keterampilan berupa pemberian tugas untuk menulis sebuah cerpen, observasi, dan wawancara.

\section{Teknik Analisis Data}

Analisis data dilakukan dengan langkah-langkah, yaitu cerpen yang dibuat siswa dibaca oleh peneliti, kemudian dideskripsikan berdasarkan instrumen penelitian, lalu skor dan persentase dihitung untuk mengetahui keterampilan menulis cerpen, dan terakhir dibuat simpulan tentang hasil analisis data.

Objek penelitian berupa cerpen yang dibuat oleh siswa dideskripsikan dalam bentuk tulisan berdasarkan beberapa indikator berupa aspek kebahasaan dan 
aspek kesastraan. Peneliti menggunakan skor agar dapat membantu melakukan analisis data cerpen.

Tabel 1. Skor Penilaian Keterampilan Menulis Cerpen

\begin{tabular}{|c|c|c|c|}
\hline \multirow{2}{*}{$\begin{array}{c}\text { Aspek } \\
\text { Penilaian }\end{array}$} & \multicolumn{3}{|c|}{ Skala Skor } \\
\hline & Baik & $\begin{array}{c}\text { Cukup } \\
\text { Baik }\end{array}$ & $\begin{array}{c}\text { Kurang } \\
\text { Baik }\end{array}$ \\
\hline \multicolumn{4}{|l|}{ Kebahasaan } \\
\hline Ejaan & 20 & 15 & 10 \\
\hline \multicolumn{4}{|l|}{ Kesastraan } \\
\hline $\begin{array}{l}\text { Tokoh } \\
\text { \& Penokohan }\end{array}$ & 20 & 15 & 10 \\
\hline Latar & 20 & 15 & 10 \\
\hline Alur & 20 & 15 & 10 \\
\hline Sudut Pandang & 20 & 15 & 10 \\
\hline
\end{tabular}

Selain itu, terdapat aspek tema dan amanat yang dideskripsikan berdasarkan kesesuaiannya dengan Komik Webtoon yang digunakan sebagai media pembelajaran.

Persentase siswa yang mencapai kategori baik, cukup baik, dan kurang baik dihitung dengan menggunakan rumus persentase. Validitas menghitung persentase tersebut dengan penghitungan secara manual melalui bantuan kalkulator. Peneliti menggunakan rumus perhitungan persentase berikut.

$$
\mathrm{P}=\mathrm{f} / \mathrm{N} \times 100 \%
$$

Keterangan:

P: Persentase

f: Frekuensi

$\mathrm{N}$ : Total frekuensi

(Kamelta, 2013)
Skor yang diperoleh siswa dijumlahkan. Kemudian, pedoman penilaian digunakan untuk mengetahui keterampilan menulis cerpen.

Tabel 2. Skala Skor Penilaian Akhir Keterampilan Menulis Cerpen

\begin{tabular}{|c|c|}
\hline Kategori & Skala Skor \\
\hline Baik & $84-100$ \\
\hline Cukup Baik & $75-83$ \\
\hline Kurang Baik & $0-74$ \\
\hline
\end{tabular}

\section{Hasil Penelitian dan Pembahasan}

Hasil dalam penelitian ini berupa hasil observasi, hasil wawancara, dan juga hasil dari analisis data. Uraiannya sebagai berikut.

\section{Hasil Observasi}

Observasi dilakukan sebelum penelitian dan ketika pembelajaran berlangsung. Hasil observasi sebelum penelitian dapat dilihat tentang siswa yang kurang minatnya dalam menulis cerpen karena sulitnya mendapatkan inspirasi. Selain itu, peneliti menemukan bahwa banyak siswa yang suka membaca Komik Webtoon. Contohnya di kelas IX-D, Komik Webtoon disukai 19 dari 32 siswa. Berdasarkan hasil observasi ketika pembelajaran berlangsung, pembelajaran dapat dikatakan berhasil karena berjalan dengan baik dan kondusif. 


\section{Hasil Wawancara}

Wawancara tidak terstruktur dilakukan pada guru Bahasa Indonesia di MTsN 2 Kota Banjarmasin. Wawancara tersebut dilakukan tanggal 4 September 2019. Berdasarkan wawancara yang dilakukan, diketahui bahwa biasanya siswa belajar menulis cerpen dengan tema bebas maupun guru yang menentukan temanya. Perbedaannya dalam penelitian yang dilakukan ini, siswa menulis cerpen berdasarkan Komik Webtoon.

Wawancara tidak terstruktur juga dilakukan pada siswa MTsN 2 Kota Banjarmasin. Pada wawancara tersebut diketahui tentang siswa di kelas IX-D yang sebagian besar sudah mengenal dan suka membaca Komik Webtoon. Oleh karena itu, Komik Webtoon digunakan sebagai media untuk memudahkan siswa menulis cerpen.

\section{Hasil Analisis Data Keterampilan} Menulis Cerpen Berdasarkan Komik

\section{Webtoon}

\section{Ejaan}

Aspek ejaan difokuskan pada pemakaian huruf yang berupa huruf kapital, penulisan kata yang terdiri dari imbuhan dan kata depan, dan penggunaan tanda baca berupa tanda (. , ? ! ”) yang sesuai kaidah. Hasilnya terhadap aspek ejaan yaitu:

Tabel 3. Keterampilan Menulis Cerpen Berdasarkan Komik Webtoon Pada Aspek Kebahasaan Berupa Ejaan

\begin{tabular}{|c|c|c|c|c|c|}
\hline $\begin{array}{c}\text { Aspek } \\
\text { Penilaian }\end{array}$ & $\begin{array}{c}\text { Skala } \\
\text { Nilai }\end{array}$ & Indikator & Skor & Jumlah & Persentase \\
\hline \multirow{3}{*}{$\begin{array}{l}\text { Ejaan } \\
\text { a. pemakaian } \\
\text { huruf } \\
\text { b. penulisan } \\
\text { kata } \\
\text { c. penggunaan } \\
\text { tanda baca }\end{array}$} & Baik & $\begin{array}{l}\text { Tingkat kebenaran } \\
\text { pemakaian huruf, } \\
\text { penulisan kata, dan } \\
\text { penggunaan tanda baca } \\
\text { mencapai } 85 \%-100 \% \text {. }\end{array}$ & 20 & 23 orang & $71,87 \%$ \\
\hline & $\begin{array}{l}\text { Cukup } \\
\text { baik }\end{array}$ & $\begin{array}{l}\text { Tingkat kebenaran } \\
\text { pemakaian huruf, } \\
\text { penulisan kata, dan } \\
\text { penggunaan tanda baca } \\
\text { mencapai } 75 \%-84 \% \text {. }\end{array}$ & 15 & 6 orang & $18,75 \%$ \\
\hline & $\begin{array}{l}\text { Kurang } \\
\text { baik }\end{array}$ & $\begin{array}{l}\text { Tingkat kebenaran } \\
\text { pemakaian huruf, } \\
\text { penulisan kata, dan } \\
\text { penggunaan tanda baca } \\
\text { mencapai } 0 \%-74 \% \text {. }\end{array}$ & 10 & 3 orang & $9,38 \%$ \\
\hline \multicolumn{4}{|l|}{\begin{tabular}{|l|} 
Jumlah \\
\end{tabular}} & 32 orang & $100 \%$ \\
\hline
\end{tabular}

Gambar 1. Tabel Aspek Ejaan

Pada 32 siswa yang diteliti, 23 siswa $(71,87 \%)$ nilainya dikategorikan baik. 6 siswa $(18,75 \%)$ nilainya dikategorikan cukup baik. Selain itu, 3 siswa $(9,38 \%)$ nilainya dikategorikan kurang baik. Oleh karena itu, dapat diketahui bahwa pada aspek ejaan, keterampilan siswa dalam menulis cerpen berdasarkan Komik Webtoon dapat dikategorikan baik $(71,87 \%)$.

\section{Tokoh dan Penokohan}

Aspek tokoh dan penokohan difokuskan pada penggunaan teknik dramatik dan analitik untuk menggambarkan karakter tokoh. Hasilnya terhadap aspek tokoh dan penokohan yaitu: 
Tabel 4. Keterampilan Menulis Cerpen Berdasarkan Komik Webtoon

Pada Aspek Kesastraan Berupa Tokoh dan Penokohan

\begin{tabular}{|c|c|c|c|c|c|}
\hline $\begin{array}{c}\text { Aspek } \\
\text { Penilaian } \\
\end{array}$ & \begin{tabular}{|c|} 
Skala \\
Nilai \\
\end{tabular} & Indikator & Skor & Jumlah & Persentase \\
\hline \multirow[t]{3}{*}{\begin{tabular}{|l|} 
Tokoh dan \\
Penokohan
\end{tabular}} & Baik & $\begin{array}{l}\text { Baik dalam menggunakan } \\
\text { teknik dramatik dan analitik } \\
\text { untuk menggambarkan } \\
\text { karakter tokoh. }\end{array}$ & 20 & 7 orang & $21,88 \%$ \\
\hline & $\begin{array}{l}\text { cukup } \\
\text { baik }\end{array}$ & $\begin{array}{l}\text { Baik dalam menggunakan } \\
\text { salah satu teknik (dramatik } \\
\text { atau analitik) untuk } \\
\text { menggambarkan karakter } \\
\text { tokoh. } \\
\end{array}$ & 15 & 24 orang & $75 \%$ \\
\hline & $\begin{array}{l}\text { kurang } \\
\text { baik }\end{array}$ & $\begin{array}{llr}\text { Kurang } & \text { baik } & \text { dalam } \\
\text { menggunakan kedua teknik } & \\
\text { (dramatik } & \text { atau analitik) } \\
\text { untuk } & \text { menggambarkan } \\
\text { karakter tokoh. } & \\
\end{array}$ & 10 & 1 orang & $3,12 \%$ \\
\hline \multicolumn{4}{|l|}{ Jumlah } & 32 orang & $100 \%$ \\
\hline
\end{tabular}

Gambar 2. Tabel Aspek Tokoh dan Penokohan

Pada 32 siswa yang diteliti, 7 siswa $(21,88 \%)$ nilainya dikategorikan baik. 24 siswa (75\%) memperoleh nilai cukup baik. Selain itu, terdapat 1 siswa $(3,12 \%)$ yang nilainya kurang baik. Oleh karena itu, dapat diketahui bahwa pada aspek tokoh dan penokohan, keterampilan siswa dalam menulis cerpen berdasarkan Komik Webtoon dapat dikategorikan cukup baik $(75 \%)$.

\section{Latar}

Aspek latar difokuskan pada penggunaan ketiga jenis latar, yaitu latar tempat, latar waktu dan latar sosialbudaya. Hasilnya terhadap aspek latar yaitu:
Tabel 5. Keterampilan Menulis Cerpen Berdasarkan Komik Webtoon Pada Aspek Kesastraan Berupa Latar

\begin{tabular}{|c|c|c|c|c|c|}
\hline $\begin{array}{c}\text { Aspek } \\
\text { Penilaian }\end{array}$ & $\begin{array}{l}\text { Skala } \\
\text { Nilai }\end{array}$ & Indikator & Skor & Jumlah & Persentase \\
\hline \multirow[t]{3}{*}{ Latar } & Baik & $\begin{array}{l}\text { Cukup detail (spesifik) } \\
\text { mendeskripsikan ketiga jenis } \\
\text { latar (tempat, waktu dan } \\
\text { sosial-budaya) dalam cerpen } \\
\text { yang dibuat. }\end{array}$ & 20 & 1 orang & $3,12 \%$ \\
\hline & $\begin{array}{l}\text { Cukup } \\
\text { baik }\end{array}$ & $\begin{array}{l}\text { Cukup detail (spesifik) } \\
\text { mendeskripsikan satu sampai } \\
\text { dua latar (latar tempat, waktu, } \\
\text { atau sosial-budaya) dalam } \\
\text { cerpen yang dibuat. }\end{array}$ & 15 & 29 orang & $90,63 \%$ \\
\hline & $\begin{array}{l}\text { Kurang } \\
\text { baik }\end{array}$ & $\begin{array}{l}\text { Latar tempat, waktu dan } \\
\text { sosial-budaya tidak jelas } \\
\text { dalam cerpen yang dibuat. }\end{array}$ & 10 & 2 orang & $6,25 \%$ \\
\hline \multicolumn{4}{|l|}{ Jumlah } & 32 orang & $100 \%$ \\
\hline
\end{tabular}

Gambar 3. Tabel Aspek Latar

Pada 32 siswa yang diteliti, 1 siswa $(3,12 \%)$ nilainya dikategorikan baik. 29 siswa $(90,63 \%)$ nilainya dikategorikan cukup baik. Selain itu, 2 siswa $(6,25 \%)$ nilainya dikategorikan kurang baik. Oleh karena itu, dapat diketahui bahwa pada aspek latar, keterampilan siswa dalam menulis cerpen berdasarkan Komik Webtoon dapat dikategorikan cukup baik $(90,63 \%)$.

\section{Alur}

Aspek alur difokuskan pada kepaduan alur dan hubungan sebab akibatnya. Hasilnya terhadap aspek alur yaitu: 
Tabel 6. Keterampilan Menulis Cerpen Berdasarkan Komik Webtoon

Pada Aspek Kesastraan Berupa Alur

\begin{tabular}{|c|c|c|c|c|c|}
\hline $\begin{array}{c}\text { Aspek } \\
\text { Penilaian }\end{array}$ & $\begin{array}{l}\text { Skala } \\
\text { Nilai }\end{array}$ & Indikator & Skor & Jumlah & Persentase \\
\hline \multirow[t]{3}{*}{ Alur } & Baik & $\begin{array}{l}\text { Cerpen yang dibuat } \\
\text { memiliki alur yang padu } \\
\text { dan memiliki hubungan } \\
\text { sebab akibat. }\end{array}$ & 20 & 26 orang & $81,25 \%$ \\
\hline & $\begin{array}{l}\text { cukup } \\
\text { baik }\end{array}$ & $\begin{array}{l}\text { Cerpen yang dibuat } \\
\text { memiliki alur yang tidak } \\
\text { padu, tetapi memiliki } \\
\text { hubungan sebab akibat. }\end{array}$ & 15 & 6 orang & $18,75 \%$ \\
\hline & $\begin{array}{l}\text { kurang } \\
\text { baik }\end{array}$ & $\begin{array}{l}\text { Cerpen yang dibuat } \\
\text { memiliki alur yang tidak } \\
\text { padu dan tidak memiliki } \\
\text { hubungan sebab akibat. }\end{array}$ & 10 & 0 orang & $0 \%$ \\
\hline \multicolumn{4}{|l|}{ Jumlah } & 32 orang & $100 \%$ \\
\hline
\end{tabular}

Gambar 4. Tabel Aspek Alur

Pada 32 siswa yang diteliti, 26 siswa $(81,25 \%)$ nilainya dikategorikan baik. 6 siswa $(18,75 \%)$ nilainya dikategorikan cukup baik. Selain itu, tidak terdapat siswa $(0 \%)$ yang nilainya dikategorikan kurang baik. Oleh karena itu, dapat diketahui bahwa pada aspek alur, keterampilan siswa dalam menulis cerpen berdasarkan Komik Webtoon dapat dikategorikan baik $(81,25 \%)$.

\section{Sudut Pandang}

Aspek sudut pandang difokuskan pada penggunaan dua jenis sudut pandang, yaitu orang pertama dan orang ketiga. Hasilnya terhadap aspek sudut pandang yaitu:
Tabel 7. Keterampilan Menulis Cerpen Berdasarkan Komik Webtoon Pada Aspek Kesastraan Berupa Sudut Pandang

\begin{tabular}{|l|l|l|l|l|l|}
\hline \multicolumn{1}{|c|}{$\begin{array}{c}\text { Aspek } \\
\text { Penilaian }\end{array}$} & $\begin{array}{c}\text { Skala } \\
\text { Nilai }\end{array}$ & \multicolumn{1}{|c|}{ Indikator } & Skor & Jumlah & Persentase \\
\hline $\begin{array}{l}\text { Sudut } \\
\text { pandang }\end{array}$ & Baik & $\begin{array}{l}\text { Penulis cerpen menggunakan } \\
\text { sudut pandang orang pertama } \\
\text { dan sudut pandang orang } \\
\text { ketiga (campuran), jelas, dan } \\
\text { logis. }\end{array}$ & 20 & 1 orang & $3,12 \%$ \\
\cline { 2 - 6 } & $\begin{array}{l}\text { cukup } \\
\text { baik }\end{array}$ & $\begin{array}{l}\text { Penulis cerpen menggunakan } \\
\text { sudut pandang orang pertama } \\
\text { atau sudut pandang orang } \\
\text { ketiga (tidak menggunakan } \\
\text { sudut pandang campuran), } \\
\text { jelas, dan logis. }\end{array}$ & 31 orang & $96,88 \%$ \\
\cline { 2 - 6 } & $\begin{array}{l}\text { kurang } \\
\text { baik }\end{array}$ & $\begin{array}{l}\text { Penulis cerpen menggunakan } \\
\text { sudut pandang yang tidak } \\
\text { jelas dan tidak logis. }\end{array}$ & 10 & 0 Orang & $0 \%$ \\
\hline Jumlah & & 32 orang & $100 \%$ \\
\hline
\end{tabular}

Gambar 5. Tabel Aspek Sudut Pandang

Pada 32 siswa yang diteliti, 1 siswa $(3,12 \%)$ nilainya dikategorikan baik. 31 siswa $(96,88 \%)$ nilainya dikategorikan cukup baik. Selain itu, tidak terdapat siswa $(0 \%)$ yang nilainya dikategorikan kurang baik. Oleh karena itu, dapat diketahui bahwa pada aspek sudut pandang, keterampilan siswa dalam menulis cerpen berdasarkan Komik Webtoon dapat dikategorikan cukup baik $(96,88 \%)$.

\section{Tema}

Aspek tema difokuskan pada kesesuaian tema cerpen dengan tema Komik Webtoon yang dibaca siswa. Hasilnya terhadap aspek tema yaitu: 
Tabel 8. Keterampilan Menulis Cerpen Berdasarkan Komik Webtoon Pada Aspek Kesastraan Berupa Tema

\begin{tabular}{|c|c|c|c|c|}
\hline $\begin{array}{c}\text { Aspek } \\
\text { Penilaian }\end{array}$ & $\begin{array}{c}\text { Skala } \\
\text { Nilai }\end{array}$ & Indikator & Jumlah & Persentase \\
\hline \multirow[t]{2}{*}{ Tema } & Baik & $\begin{array}{l}\text { Tema cerpen sesuai dengan tema } \\
\text { dalam Komik Webtoon }\end{array}$ & 32 orang & $100 \%$ \\
\hline & $\begin{array}{l}\text { Kurang } \\
\text { Baik }\end{array}$ & $\begin{array}{l}\text { Tema cerpen tidak sesuai dengan } \\
\text { tema dalam Komik Webtoon }\end{array}$ & 0 orang & $0 \%$ \\
\hline \multicolumn{3}{|l|}{ Jumlah } & 32 orang & $100 \%$ \\
\hline
\end{tabular}

Gambar 6. Tabel Aspek Tema

Pada 32 siswa yang diteliti, seluruhnya (100\%) keterampilannya dalam menulis cerpen berdasarkan Komik Webtoon pada aspek tema bisa dikategorikan baik. Hal ini karena bisa menulis cerpen dengan tema yang sesuai dengan tema Komik Webtoon yang sudah mereka baca.

\section{Amanat}

Aspek amanat difokuskan pada kesesuaian amanat cerpen dengan amanat Komik Webtoon yang dibaca siswa. Hasilnya terhadap aspek amanat yaitu:

Tabel 9. Keterampilan Menulis Cerpen Berdasarkan Komik Webtoon Pada Aspek Kesastraan Berupa Amanat

\begin{tabular}{|l|c|l|l|l|}
\hline $\begin{array}{c}\text { Aspek } \\
\text { Penilaian }\end{array}$ & $\begin{array}{c}\text { Skala } \\
\text { Nilai }\end{array}$ & \multicolumn{1}{|c|}{ Indikator } & Jumlah & Persentase \\
\hline Amanat & Baik & $\begin{array}{l}\text { Amanat cerpen sesuai dengan } \\
\text { amanat dalam Komik Webtoon }\end{array}$ & 31 orang & $96,88 \%$ \\
\cline { 2 - 5 } & $\begin{array}{l}\text { Kurang } \\
\text { Baik }\end{array}$ & $\begin{array}{l}\text { Amanat cerpen tidak sesuai } \\
\text { dengan amanat dalam Komik } \\
\text { Webtoon }\end{array}$ & 1 orang & $3,12 \%$ \\
\hline Jumlah & & 32 orang & $100 \%$ \\
\hline
\end{tabular}

Gambar 7. Tabel Aspek Amanat
Pada 32 siswa yang diteliti, 31 siswa $(96,88 \%)$ bisa dikategorikan baik karena bisa menulis cerpen dengan amanat yang sesuai dengan amanat Komik Webtoon yang sudah dibaca. Selain itu, 1 siswa $(3,12 \%)$ dikategorikan kurang baik karena tidak ditemukan amanat dalam cerpennya. Oleh karena itu, disimpulkan bahwa pada aspek amanat, keterampilan siswa dalam menulis cerpen berdasarkan Komik Webtoon dapat dikategorikan baik $(96,88 \%)$.

Skor akhir keterampilan menulis cerpen masing-masing siswa dapat diketahui dari analisis data pada berbagai aspek di atas. Skor akhir tersebut yaitu:

Tabel 10. Analisis Data Keterampilan Menulis Cerpen Berdasarkan Komik Webtoon

\begin{tabular}{|l|l|l|l|}
\hline No. & \multicolumn{1}{|c|}{ Nama } & \multicolumn{1}{|c|}{$\begin{array}{l}\text { Jumlah } \\
\text { Skor }\end{array}$} & Kategori \\
\hline 1. & $\begin{array}{l}\text { Aditya Fery } \\
\text { Setiawan }\end{array}$ & 80 & $\begin{array}{l}\text { Cukup } \\
\text { baik }\end{array}$ \\
\hline 2. & Ahmad Rizky & 80 & $\begin{array}{l}\text { Cukup } \\
\text { baik }\end{array}$ \\
\hline 3. & $\begin{array}{l}\text { Atika Maisya } \\
\text { Rahma Sari }\end{array}$ & 75 & $\begin{array}{l}\text { Cukup } \\
\text { baik }\end{array}$ \\
\hline 4. & Azmi Aidina & 85 & Baik \\
\hline 5. & $\begin{array}{l}\text { Dhea Aprilia } \\
\text { Savitri }\end{array}$ & 85 & Baik \\
\hline 6. & $\begin{array}{l}\text { Eka Sukma } \\
\text { Hayati }\end{array}$ & 75 & $\begin{array}{l}\text { Cukup } \\
\text { baik }\end{array}$ \\
\hline 7. & $\begin{array}{l}\text { Farah Gina } \\
\text { Zahrah }\end{array}$ & 80 & $\begin{array}{l}\text { Cukup } \\
\text { baik }\end{array}$ \\
\hline 8. & $\begin{array}{l}\text { Febrian Dwi } \\
\text { Cahyo } \\
\text { Muharom }\end{array}$ & 85 & Baik \\
\hline
\end{tabular}




\begin{tabular}{|c|c|c|c|}
\hline 9. & $\begin{array}{l}\text { Hendri } \\
\text { Natalianingrum }\end{array}$ & 85 & Baik \\
\hline 10. & $\begin{array}{l}\text { Ilham } \\
\text { Ahjatunnajah } \\
\text { Fahmi }\end{array}$ & 90 & Baik \\
\hline 11. & Indriana Safira & 90 & Baik \\
\hline 12. & Karina Salsabila & 85 & Baik \\
\hline 13. & $\begin{array}{l}\text { M. Adji } \\
\text { Pangestu }\end{array}$ & 75 & $\begin{array}{l}\text { Cukup } \\
\text { baik }\end{array}$ \\
\hline 14. & $\begin{array}{l}\text { M. Iskandar } \\
\text { Kurnain }\end{array}$ & 80 & $\begin{array}{l}\text { Cukup } \\
\text { baik }\end{array}$ \\
\hline 15. & M. Alvin Fajar & 65 & $\begin{array}{l}\text { Kurang } \\
\text { baik }\end{array}$ \\
\hline 16. & $\begin{array}{l}\text { M. Fauzi } \\
\text { Rahman }\end{array}$ & 85 & Baik \\
\hline 17. & M. Ihsan Praja & 85 & Baik \\
\hline 18. & M. Rif'at Alhadi & 85 & Baik \\
\hline 19. & $\begin{array}{l}\text { M. Rizky } \\
\text { Zamzami }\end{array}$ & 75 & $\begin{array}{l}\text { Cukup } \\
\text { baik }\end{array}$ \\
\hline 20. & M. Yusni & 85 & Baik \\
\hline 21. & $\begin{array}{l}\text { Nabila Fatiha } \\
\text { Rizkina }\end{array}$ & 95 & Baik \\
\hline 22. & $\begin{array}{l}\text { Nahda Laili } \\
\text { Khairizqa }\end{array}$ & 90 & Baik \\
\hline 23. & Nazla Fatima & 80 & $\begin{array}{l}\text { Cukup } \\
\text { baik }\end{array}$ \\
\hline 24. & Nazlatul Audah & 85 & Baik \\
\hline 25. & Ni'matul Udzma & 85 & Baik \\
\hline 26. & Risma Audina & 85 & Baik \\
\hline 27. & $\begin{array}{l}\text { Rizkiya Al- } \\
\text { Qamilah }\end{array}$ & 85 & Baik \\
\hline 28. & Salma & 85 & Baik \\
\hline 29. & $\begin{array}{l}\text { Salsa Amelia } \\
\text { Safitri }\end{array}$ & 75 & $\begin{array}{l}\text { Cukup } \\
\text { baik }\end{array}$ \\
\hline 30. & Silma Najwa & 90 & Baik \\
\hline 31. & $\begin{array}{l}\text { Siti Nadhir Nur } \\
\text { Chozimah }\end{array}$ & 90 & Baik \\
\hline 32. & $\begin{array}{l}\text { Siti Nor } \\
\text { Srirahmi }\end{array}$ & 85 & Baik \\
\hline
\end{tabular}

Berdasarkan tabel di atas, diperoleh hasil akhir keterampilan menulis cerpen berdasarkan Komik Webtoon.
Tabel 11.Hasil Akhir Keterampilan Menulis Cerpen Berdasarkan Komik Webtoon

\begin{tabular}{|c|c|c|}
\hline \multicolumn{3}{|c|}{ Hasil Akhir } \\
\hline Kategori & Jumlah & Persentase \\
\hline Baik & 21 siswa & $65,63 \%$ \\
\hline Cukup baik & 10 siswa & $31,25 \%$ \\
\hline Kurang baik & 1 siswa & $3,12 \%$ \\
\hline Jumlah & 32 siswa & $100 \%$ \\
\hline
\end{tabular}

\section{Simpulan dan Saran}

\section{Simpulan}

Berdasarkan hasil penelitian, dapat disimpulkan bahwa Komik Webtoon baik untuk digunakan dalam pembelajaran menulis cerpen. Hal tersebut dilihat dari respons siswa selama proses pembelajaran dan hasil analisis data cerpen yang dibuat siswa. Pembelajaran menulis cerpen berdasarkan Komik Webtoon dapat berjalan dengan baik. Selain itu, siswa aktif dan antusias selama pembelajaran berlangsung.

Berdasarkan aspek-aspek yang diteliti, diketahui bahwa siswa kelas IX-D MTsN 2 Kota Banjarmasin paling banyak menguasai aspek kesastraan berupa alur dan aspek yang paling kurang dikuasai siswa, yaitu aspek kebahasaan berupa ejaan. Selain itu, diketahui bahwa siswa baik dalam membuat cerpen berdasarkan tema dan amanat yang terdapat dalam Komik Webtoon yang dibaca. 
Berdasarkan hasil analisis data, diketahui bahwa $65,63 \%$ siswa dikategorikan baik, $31,25 \%$ siswa dikategorikan cukup baik, dan 3,12\% siswa dikategorikan kurang baik. Oleh karena itu, hasil keterampilan menulis cerpen berdasarkan Komik Webtoon siswa di kelas IX-D MTsN 2 Kota Banjarmasin dapat dikategorikan baik (terampil), dengan persentase $65,63 \%$.

\section{Saran}

Berdasarkan penelitian ini diketahui bahwa Komik Webtoon baik digunakan sebagai media pembelajaran menulis cerpen. Karena hal tersebut, diharapkan media Komik Webtoon ini dapat dipakai oleh guru pada materi menulis cerpen atau mencoba menggunakannya sebagai media pada materi pembelajaran yang lain.

Pada penelitian ini, keterampilan menulis cerpen diteliti berdasarkan aspek kebahasaan dan aspek kesastraan. Untuk peneliti yang akan datang, apabila meneliti tentang keterampilan menulis cerpen agar menyamakan teknik analisis data terhadap aspek-aspek yang diteliti.

\section{DAFTAR RUJUKAN}

\section{a. Dari Buku Teks}

Arikunto, Suharsimi. (2010). Prosedur Penelitian Suatu Pendekatan Praktik. Yogyakarta: Rineka Cipta.

Dalman. (2016). Keterampilan Menulis. Jakarta: Rajawali Pers.

Hermawan, Sainul. (2009). Belajar Menulis Puisi \& Cerpen. Banjarbaru: Scripta Cendekia.

Kosasih, E. (2014). Dasar-Dasar Keterampilan Bersastra. Bandung: Yrama Widya.

Kurniawan, Heru dan Sutardi. (2012). Penulisan Sastra Kreatif. Yogyakarta: Graha Ilmu.

Laksana, A.S. (2013). Creative Writing. Jakarta: GagasMedia.

Nurgiyantoro, Burhan. (2005). Sastra Anak (Pengantar Pemahaman Dunia Anak). Yogyakarta: Gadjah Mada University Press.

Nurgiyantoro, Burhan. (2015). Teori Pengkajian Fiksi. Yogyakarta: Gadjah Mada University Press.

Purnawanto, Budy. (2010). Manajemen SDM Berbasis Proses. Jakarta: Grasindo.

Rosidi, Imron. (2009). Menulis... Siapa Takut?. Yogyakarta: Kanisius.

Sugiyono. (2014). Metode Penelitian Kuantitatif Kualitatif dan $R \& D$. Bandung: Alfabeta. 
Sukino. (2010). Menulis itu Mudah. Yogyakarta: Pustaka Populer.

Sunendar, Dadang. (2016). Pedoman Umum Ejaan Bahasa Indonesia. Jakarta: Badan Pengembangan dan Pembinaan Bahasa.

Tarigan, Guntur Henry. (1993). Strategi dan Pembelajaran Bahasa. Bandung: Angkasa.

Tarigan, Guntur Henry. (2013). Menulis Sebagai Suatu Keterampilan Berbahasa. Jakarta: Angkasa Bandung.

Waluyo, Budi. (2018). Bahasa dan Sastra Indonesia 3 untuk Kelas IX SMP dan $M T s$. Solo: PT Tiga Serangkai Pustaka Mandiri.

Wicaksono, Andri. (2014). Menulis Kreatif Sastra dan Beberapa Model Pembelajarannya. Yogyakarta: Garudhawaca.

\section{b. Dari Skripsi/Tesis/Disertasi}

Akmalia, Anis. (2012). Upaya Peningkatan Keterampilan Menulis Cerpen Siswa Kelas XE SMA Negeri 2 Magelang dengan Strategi Pembelajaran Berbasis Masalah. Skripsi. Universitas Negeri Yogyakarta.

Atika, Aulia Ika. (2018). Pengembangan Media Pembelajaran Menulis Drama dengan Webtoon di Kelas VIII SMP. Tesis. Universitas Lampung.

Febrianti, Tina Lusi. (2017). Peningkatan Kemampuan Menulis Cerpen Menggunakan Media Gambar Siswa Kelas IX SMPN 4 NARMADA Tahun Ajaran 2016-2017. Skripsi. Universitas Mataram.
Kurniawati. (2018). Kemampuan Menulis Teks Cerpen Siswa Kelas XI SMA Negeri 9 Makassar. Skripsi. Universitas Negeri Makassar.

Musfiroh, Daraini. (2017). Pengaruh Penggunaan Media Komik Terhadap Keterampilan Bercerita Siswa Kelas V SD Negeri Sinduadi 1 Kecamatan Mlati Kabupaten Sleman Tahun Ajaran 2016/2017. Skripsi. Universitas Negeri Yogyakarta.

Nilariyanti, Eka. (2007). Pembelajaran Matematika Model Kooperatif "Tipe Team-Assisted Individualization (TAI)" Pada Siswa Kelas VII MTs Negeri Mulawarman Banjarmasin Tahun Pelajaran 2006/2007. Skripsi. Universitas Lambung Mangkurat.

Rahman, Muhammad Aulia. (2019). Pemahaman Kosakata Bahasa Indonesia dalam Teks Deskripsi pada Peserta Didik Kelas IX-D MTs Negeri 2 Banjarmasin. Skripsi. Universitas Lambung Mangkurat.

Sari, Herda Wulan. (2011). Meningkatkan Kemampuan Siswa dalam Pembelajaran Seni Tari Melalui Tari Tirik Kuala Metode Demonstrasi Pada Siswa Kelas VII D Di MTsN Mulawarman Banjarmasin. Skripsi. STKIP PGRI Banjarmasin.

Susanti, Henny. (2010). Studi tentang Kebiasaan Belajar Siswa Berprestasi pada MTsN Mulawarman Banjarmasin. Skripsi. Universitas Islam Kalimantan. 


\section{c. Dari Jurnal}

Fajriani, Rizky, Dadan Djuanda dan Ali Sudin. (2017). Meningkatkan Keterampilan Menulis Paragraf Melalui Penerapan Model Pembelajaran Concept Sentence Dengan Permainan Detective Sherlock Holmes And The Adventure Book. Jurnal Pena Ilmiah, Vol. 2, No. 1.

Kamelta, Edno. (2013). Pemanfaatan Internet oleh Mahasiswa Jurusan Teknik Sipil Fakultas Teknik Universitas Negeri Padang. CIVED, Vol. 1, No. 2.

Linda, Wirda dan Ayu Armia Gusti. (2017). Keterampilan Menulis Kreatif Cerpen Menggunakan Media Audio Siswa Kelas XII SMAN 1 Kecamatan Payakumbuh. Jurnal Bahastra, Vol. 37, No. 1.

Rachman, Rizki Nurpiana. (2017). Peningkatan Kemampuan Menulis Cerpen Melalui Penggunaan Media Audiovisual Tayangan "Televisi Cermin Kehidupan" TRANS 7. Jurnal Diksatrasia, Vol. 1, No. 1.

Siki, Ferdinandus, Sunoto, dan Roekhan. (2017). Upaya Meningkatkan Kemampuan Menulis Cerpen Berdasarkan Pengalaman Pribadi dengan Strategi Pemodelan. Jurnal Pendidikan, Vol. 2, No. 12.

Sudarto. (2016). Keterampilan dan Nilai sebagai Materi Pendidikan dalam Perspektif Islam. Jurnal Al Lubab, Vol. 1, No. 1.

Susandi, Anita Kurnia Rachman. (2019). Keterampilan Menulis Cerpen dengan Teknik Ubah Diary Mahasiswa FKIP
Budi Utomo Malang. Jurnal Kembara, Vol. 5, No. 2.

Umar, Seniwati. (2016). Peningkatan Keterampilan Menulis Cerpen dengan Strategi Copy The Master Melalui Media Audiovisual pada Siswa Kelas IXa SMP Negeri 2 Tolitoli. Jurnal Kreatif Tadulako Online, Vol. 4, No. 6.

\section{d. Dari Internet}

Agnes, Tia. (2016). Pembaca LINE Webtoon Indonesia Terbesar di Dunia. Diakses tanggal 10 Maret 2019 dari https://hot.detik.com/art/d3274551/pembaca-line-webtoonindonesia-terbesar-di-dunia.

Hulett, Leon. (2018). What is the Difference Between a Skill and an Ability?. Diakses tanggal 30 Januari 2020 dari https://www.quora.com/what-is-thedifference-between-a-skill-and-anability.

Krishnamurthy, Vasudha. (2019). What is the Difference Between a Skill and an Ability?. Diakses tanggal 30 Januari 2020 dari https://www.quora.com/what-is-thedifference-between-a-skill-and-anability. 